\title{
KALENDARZ LITURGICZNY KOŚCIOŁA PRAWOSŁAWNEGO W RUMUNII - LOKALNA TRANSFORMACJA TRADYCJI BIZANTYJSKIEJ
}

\author{
EWA Kocój
}

\begin{abstract}
Ewa Kocój, Kalendarz liturgiczny Kościoła prawosławnego w Rumunii - lokalna transformacja tradycji bizantyjskiej (The Liturgical calendar of the orthodox church in Romania - a local transformation of the byzantine tradition).

Balcanica Posnaniensia. Acta et studia, XIX, Poznań 2012, Wydawnictwo Instytutu Historii UAM, pp. 95-110, ISBN 978-83-63-047-17-7, ISSN 0239-4278. Polish text with a summary in English.
\end{abstract}

Ewa Kocój, Uniwersytet Jagielloński, Instytut Kultury, ul. Prof. S. Łojasiewicza 4, 30-348 Kraków, Polska Poland

Kalendarz liturgiczny, wypływający z bizantyjskiej praktyki Kościoła oraz kalendarz ludowy, pozostałość dawnych rolniczych tradycji, stanowią dwa podstawowe źródła, które składają się na miarę czasu we współczesnej rumuńskiej kulturze prawosławnej. Kalendarze te, powstałe na bazie wiary i wierzeń, wyznaczają najważniejsze święta, a wraz z nimi obrzędy i zwyczaje praktykowane przez wiernych. W wielu z nich odnajdujemy wierzenia ukształtowane jeszcze w kulturze bizantyjskiej, które siłą tradycji, tak silnie podtrzymywanej w duchowości Kościoła prawosławnego, przetrwały przez wieki do czasów współczesnych ${ }^{1}$.

W Kościele prawosławnym na terenie Rumunii oficjalnie w życiu liturgicznym stosuje się obecnie dwa różne kalendarze: kalendarz gregoriański, zwany coraz częściej kalendarzem neo-juliańskim lub nowo-juliańskim oraz kalendarz juliański. Aż do początków XX wieku Rumuni, podobnie jak cały Kościół wschodni, używali oficjalnie kalendarza juliańskiego (tzw. starego stylu), wyznaczającego rytm życia religijnego oraz świeckiego. Twórcą tego kalendarza był aleksandryjski astronom Sosigenes, który w 46 r. p.n.e. opracował go według wzorów egipskich na polecenie Juliusza Cezara. Kalendarz ten, ze względu na utratę synchronizacji z porami roku, został

${ }^{1}$ G. S. Bebis, Święta Tradycja, [w:] Prawostawie. Światto ze Wschodu, red. K. Leśniewski, Lublin 2009, s. 17-24. 
zmodyfikowany w 9 r. p.n.e. na polecenie cesarza Augusta ${ }^{2}$. Po przyjęciu go przez bizantyjski świat chrześcijański, stopniowo zaczął być dostosowywany do jego potrzeb. $\mathrm{W}$ jego strukturach uformował się kalendarz liturgiczny, czerpiąc ze starszych i różnorodnych w starożytnym świecie tradycji mierzenia czasu³. Proces formowania kalendarza liturgicznego był rozłożony w czasie i skomplikowany. Polegał on zarówno na ustalaniu ważnych teologicznie świąt, jak i na łączeniu imion szczególnie zasłużonych wiernych z poszczególnymi dniami roku. Początkowo, w czasach prześladowań, nie istniał jeden, powszechny i obowiązujący wszystkich chrześcijan kalendarz liturgiczny. Poszczególne diecezje, miasta, a nawet monastery, posiadały własne partykularne kalendarze, stąd też dużą rolę w formowaniu kalendarza chrześcijańskiego miała tzw. faza lokalna. Już od II wieku istniał zwyczaj wspominania męczenników chrześcijaństwa, troszczenia o ich miejsca pochówku i wspominanie ich w modlitwie, jednak - wobec prześladowan - miał on raczej charakter nieoficjalny. Wzorował się także na kulcie postaci z kalendarzy przedchrześcijańskich ${ }^{4}$, przede wszystkich obrzędach tzw. kultów misteryjnych (np. kult Kybele i Attisa, Mitry, Asklepiosa, misteria eleuzyńskie), szeroko rozpowszechnionych w kulturze grecko-wschodniej (hellenistycznej) $)^{5}$

Jednocześnie, już w 312 r. cesarz Konstantyn Wielki lekko zmodyfikował kalendarz juliański, ustalając początek nowego roku na 1 września i wprowadzając 15-letni cykl spisów dla celów podatkowych (tzw. indykcji). W Imperium Rzymskim rok finansowy rozpoczynał się wraz z indictio (obwieszczenie), które ogłaszał cesarz. Co 15 lat dokonywano przeglądu stanu finansów państwa i ogłaszano wysokość podatków ${ }^{6}$. Wraz z uznaniem chrześcijaństwa za oficjalne wyznanie, pojawiła się potrzeba przystosowania kalendarza do cyklu liturgicznego. $Z$ tego powodu, od IV w. do powstających lokalnych kościelnych kalendarzy liturgicznych poczęto dodawać imiona szczególnie zasłużonych wyznawców i lokalnie czczonych patronów ${ }^{7}$ Kościół, poprzez swoich hierarchów, tworzył listy świętych czczonych lokalnie, które z czasem przekształciły się w większe kalendarze. $Z$ ich połączenia (zwłaszcza kalendarzy wielkich metropolii), od IV w. zaczęły powstawać w Bizancjum tzw. kalendarze o charakterze powszechnym ${ }^{8}$.

${ }^{2}$ Szerzej na ten temat: H. Wąsowicz, Kalendarz juliański i gregoriański, [w]: Czas i kalendarz, red. Z. Kijas, Kraków 2001, s. 117-158; H. Wąsowicz, Kalendarz chrześcijański, [w:] Czas i kalendarz, s. 77-115; E. G. Richards, Odmierzanie czasu, Warszawa 1999, s. 197.

${ }^{3}$ ks. J. Naumowicz, Geneza chrześcijańskiej rachuby lat. Historyczno-teologiczne podstawy systemu Dionizego Mniejszego, Kraków 2000, s. 19-27; E. G. Richards, op. cit., s. 199.

${ }^{4}$ M. Skabałłanowicz, Tołkowyj Tipikon. Objasnitielnoje izłożenija Tipikona s istoriczeskim wwiedienijem, Moskwa 2004, s. 276.

${ }^{5}$ A. F. v. Rohrscheidt-Schwaben, Historia liturgii chrześcijańskiej, [dok. elektr.] http://www.kus. mikronacje.info/node/171 [odczyt: 3.05.12].

${ }^{6}$ ks. J. Naumowicz, op. cit., s. 25.

${ }^{7}$ H. Wąsowicz, Kalendarz chrześcijański, op. cit., s. 136; J. Charkiewicz, Święci w kalendarzowej praktyce liturgicznej Kościoła wschodniego, Elpis, nr 2011, s. 205-210.

8 J. Charkiewicz, op. cit., s. 210-213. 
Kształtowanie się teologii wpłynęło na rozwój świąt i wyznaczanie im dat w liturgicznym kalendarzu chrześcijańskim. Już podczas obrad pierwszego Soboru Powszechnego w Nicei podjęto decyzje w sprawie obchodów daty najważniejszego i pierwszego święta chrześcijan - Paschy9. Kolejno umieszczano w kalendarzach daty wielkich świąt związanych postacią Jezusa ${ }^{10}$. Przyznanie tytułu Matki Bożej Teothokos (Bogurodzicy) na Soborze Efeskim w 431 r., spowodowało silny rozwój jej kultu, powstanie świąt Jej zadedykowanych oraz stopniowe umieszczanie ich kalendarzu liturgicznym ${ }^{11}$. $\mathrm{O}$ ich historycznym rozwoju kolejnych świąt na Wschodzie pozwala nam wnioskować m.in. powstały w VI wieku w monastyrze św.

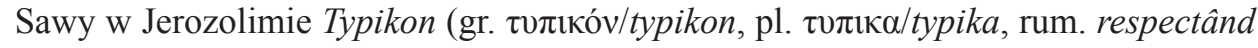
ordinea; scs: оүставъ/ustav), czyli księga zawierająca opis rytuałów nabożeństw obchodzonych przez Kościół w ciągu roku. Najprawdopodobniej jest on dziełem kilku autorów, przede wszystkim św. Sawy (V/VI w)., a także św. Sofroniusza i św. Jana Damasceńskiego. Tradycja liturgiczna tego Typikonu wpłynęła na zwyczaje i praktyki doroczne całego prawosławnego świata. W IX wieku, za czasów Teodora Studyty, Typikon ten został przyjęty w monastyrze Studion w Konstantynopolu. Tu dokonała się liturgiczna synteza, która włączyła do Typikonu praktyki świąteczne Kościoła Konstantynopolitańskiego (Haghia Sophia). Synteza dokonana przez studytów została przyjęta przez inne lokalne wschodnie kalendarze liturgiczne, stając się w większości regionów Wschodu do XIX wieku dominującym typikonem prawosławia, według którego sprawowano święta w cyklu dorocznym ${ }^{12}$.

Ważnym okresem w dziejach kalendarza juliańskiego był VII wiek, kiedy to wprowadzono w nim kolejne zmiany, ustalając nowy sposób liczenia tzw. roku pierwszego. W miejsce założenia Rzymu w kalendarzu juliańskim (753 r. p.n.e.), przyjęto - wzorem tradycji hebrajskiej - wydarzenie, jakim było stworzenia świata, oparte i wyliczone według tradycji Starego Testamentu (Septuaginty) ${ }^{13}$. Ustalono wówczas, że rachubę lat należy prowadzić od początku stworzenia świata, którego datę na podstawie różnych skomplikowanych obliczeń wyznaczono pierwotnie na dzień 21 marca 5509 roku przed Chrystusem, była to tzw. „era protobizantyńska”. Erę tę za czasów cesarza Justyniana zmodyfikowano i datę stworzenia świata przesunięto na dzień 1 września 5508 roku przed Chrystusem. Ten sposób liczenia czasu nazwano „erą bizantyńską", a ze względu na praktyczny system obliczeń, zastosowano ją w aktach państwowych i kościelnych oraz literaturze historycznej ${ }^{14}$. Szczególnie popular-

${ }^{9}$ Dokumenty Soborów Powszechnych. Tekst grecki, laciński, polski, T. I (325-787), opr. ks. A. Baron, ks. H. Pietras SJ, Kraków 2003, s. 53.

${ }^{10}$ ks. M. Janocha, Ukraińskie i białoruskie ikony świateczne w dawnej Rzeczypospolitej, Warszawa 2001, passim.

11 Tamże, s. 127, 151.

12 Warto podkreślić, że nowe święta wchodzące do kalendarza, nie musiały wiązać się jednak z kanonizacjami.

13 ks. J. Naumowicz, op. cit., s. 19-30.

14 Szerzej na ten temat: ks. ks. J. Naumowicz, op. cit., s. 109-112. 
na stała się od X wieku w krajach prawosławnych, które używały jej aż do upadku Bizancjum w 1453 roku, a nawet dłużej ${ }^{15}$.

Kalendarz juliański obowiązywał w Kościele Prawosławnym w Rumunii do 1 października 1924 r. W tym roku przyjęto tu, po wieloletnich sporach, kalendarz gregoriański. Rumunia, wspólnie z innymi kościołami prawosławnymi przechodzącymi na kalendarz gregoriański, zdecydowała się jednak zachować jednolitą datę obchodzenia święta Wielkanocy według kalendarza juliańskiego ${ }^{16}$. $Z$ tego powodu kalendarz ten, współcześnie coraz chętniej nazywany jest kalendarzem neo-juliańskim, a nie gregoriańskim.

Trudno jednoznacznie wskazać dokładną datę ukształtowania się liturgicznego kalendarza kościoła prawosławnego. W Rumunii, podobnie jak w innych krajach prawosławnych, składa się on obecnie z trzech zachodzących na siebie cykli, które są ze sobą ściśle powiązane symbolicznie. Znaczna część z nich zaczęła wchodzić do roku liturgicznego już w pierwszych wiekach kultury bizantyjskiej, stopniowo wypracowując kanon roku liturgicznego. Cykle te dzielą codzienny czas życia człowieka, nadając mu wymiar sakralny. Dzięki niemu, człowiek ,sięga poza zasłonę wieczności”, wspominając najważniejsze momenty historii zbawienia, postacie, które dostapiły przebóstwienia oraz nadając swojemu życiu sens uniwersalny. Kalendarz prawosławia rozpoczyna się od tzw. cyklu dobowego ${ }^{17}$, prowadzi przez cykl tygodniowy, uświadamiając stopniowo wiernym symbolikę cyklu rocznego.

\section{Cykl dobowy}

Podstawowym cyklem w kalendarzu prawosławnym jest tzw. cykl dobowy. Pozwala on mnichom każdego dnia na życie wedle specyficznego rytmu, w którym myśli zatopione są w Bogu, modlitwie, pracy i odpoczynku. Także na realizację w życiu wspólnotowym życia indywidulanego, tak pięknie oddawanego przez greckie słowo monachos czy rosyjskie inako ${ }^{18}$.

${ }^{15}$ Rautman M., Daily Life in the Byzantine Empire, Greenwood Publishing Group, 2006 [dok. elektr.] http://books.google.ca/books?id=hs3iEyVRHKsC\&printsec=frontcover\&dq=Daily+Life+in+the+By zantine + Empire $\# \mathrm{v}=$ onepage $\& \mathrm{q}=$ Daily $\% 20 \mathrm{Life} \% 20 \mathrm{in} \% 20$ the $\% 20$ Byzantine $\% 20$ Empire $\& \mathrm{f}=$ false

16 Photius of Traditsa, The 70th Anniversary of the Pan-Orthodox Congress, Part II of II A Major Step on the Path Towards Apostasy, http://orthodoxinfo.com/ecumenism/photii_2.aspx; E. Theodossiou1, V. N. Manimanis, M.S. Dimitrijevi'c, Six calendar systems in the European history from 18th to 20th Century, Bulgarian Astronomical Journal 16, s. 109-; 233; tekst dostępny także na: http://www.astro. bas.bg/AIJ/issues/n16/ETheodos.pdf

17 Nabożeństwa cyklu dobowego [dok. elektr.] http://teatrnn.pl/leksykon/node/3233/prawos\%C5\%82awie_na_lubelszczy\%C5\%BAnie [odczyt: 24.05.12].

${ }^{18}$ Bp Maximos (E. Aghiorgoussis), Monastycyzm, [w:] Prawostawie. Światto wiary i zdrój doświadczenia, Lublin 1999, s. 133-142; bp Jakub (Kostiuczuk), Monastycyzm wschodni, [w:] Życie monastyczne w Rzeczypospolitej, s. 11-22. 
Cykl dobowy życia monastycznego, nazywany także Liturgia godzin lub oficjum ${ }^{19}$, jest nierozerwalnie związany ze specjalnym pojmowaniem i wartościowaniem czasu, któremu odpowiadają ukształtowane w ciągu wieków nabożeństwa. Każde z nich jest głęboko symboliczne, zarówno na poziomie czasu, w którym się odbywa, jak i doboru tekstów modlitw. W cyklu dobowym prawosławia szczególnie wartościowane są dwa momenty - zachodu i wschodu słońca. Kościół prawosławny stoi na stanowisku, że symbolika światła, jego dobowe pojawianie się i znikanie, wykraczają poza zwykłe zjawisko przyrody ${ }^{20}$. Ich zachowanie podporządkowane zostało bogatej teologii chrześcijańskiej i ma związek z całą historią zbawienia. Najważniejszym przesłaniem tego cyklu jest misterium paschalne. Następstwo nocy i dnia, przejście od wieczoru, poprzez noc do poranka i wschodu słońca są tu symbolem śmierci i zmartwychwstania Chrystusa ${ }^{21}$, a zarazem są przypomnieniem najważniejszych wydarzeń świętej historii chrześcijaństwa, które w Kościele uświęcone zostają poprzez specjalne modlitwy, odbywające się o stałej porze. W tradycji prawosławnej najważniejsze modlitwy dobowe podporządkowane zostały rytmowi słońca. W cyklu dobowym powstało siedem modlitw, które powinny przypadać w określonym czasie. Trzy z nich przyporządkowane są nocy: wieczernia, powieczerze, polunosznica; cztery - dniu: jutrznia wraz nabożeństwem pierwszej godziny, trzecia, szósta i dziewiąta godzina. Tradycja wyznania nadała temu podziałowi i związanym z nim modlitwom specjalne znaczenia. Z jednej strony, ukazują one akt Bożej kreacji świata i historię zbawienia; z drugiej - wzywają do postawy pokory, uświadomienia własnych słabości i konieczności przemiany życia.

Nabożeństwa cyklu dobowego są związane z tzw. godzinami kanonicznymi (czasami). Początkowi doby odpowiada jedna z najważniejszych modlitw odprawiana po zachodzie słońca, nazywana nabożeństwem wieczornym, czyli potocznie wieczerniq (rum. slujba de seară, vecernia) ${ }^{22}$. Warto podkreślić, że w monastyrach Rumunii, podobnie jak to było w starożytnej Jerozolimie, rozpoczyna się ona wezwaniem na modlitwę za pomocą liturgicznych instrumentów. Najważniejszym z nich jest w Rumunii biło (toacă).

Po wezwaniu na wieczernię, mnisi zbierają się w świątyni na wspólną modlitwę. Zazwyczaj, w monastyrach położonych w wioskach czy miastach, uczestniczą w niej także wierni. Mimo tego, że w prawosławiu wieczernia otwiera nowy dzień liturgiczny, czas jej odprawiania - moment przełomu dnia i nocy - przywodzi na myśl zachód życia człowieka, ciemność i śmierć. Całe jej misterium jest także przypomnieniem świętej historii starotestamentowej, poczynając od chaosu istniejącego przed stworzeniem świata, poprzez powołanie świata do życia, stworzenie pierwszych ludzi, ich

19 B. Bobrinskoy, Życie liturgiczne, Warszawa 2004, s. 23.

${ }^{20}$ ks. A. C. Calivas, op. cit., s. 53.

${ }^{21}$ B. Bobrinskoy, op. cit., s. 26.

${ }^{22}$ Ceaslov tipărit cu aprobarea Sfântului Sinod şi cu binecuvântarea prea Fericitului Părinte Teoctist Patriarhul Bisericii Ortodoxe Române, Bucureşti 2001, s. 152-163. 
upadek w grzech, skruchę, oczekiwanie Mesjasza, Jego objawienie w ciele człowieczym, śmierć i zmartwychwstanie ${ }^{23}$.

W monastyrach Rumunii o zmierzchu, po wieczerni, odprawiane jest kolejne nabożeństwo nazywane powieczerzem (rum. Pavecernița). Zazwyczaj odmawia się je przed udaniem na spoczynek, po posiłku. Ale w praktyce monastycznej często łączy się je także z wieczernią. W zależności od roku kalendarzowego, odprawiane jest tzw. wielkie lub małe powieczerze ${ }^{24}$. Wielkie sprawowane jest zazwyczaj we wszystkie dni Wielkiego Postu, z wyjątkiem soboty i niedzieli oraz kilku specjalnych dni tego okresu. Małe powieczerze odmawia się we wszystkie dni roku, z wyjątkiem pierwszych pięciu dni tygodnia w czasie całego Wielkiego Postu (poniedziałek-piątek) oraz dni, w których odprawia się w cerkwi tzw. denie $e^{25}$.

W niektórych monastyrach - w kaplicach lub we własnej celi - w nocy odprawiane jest jeszcze inne nabożeństwo zwane polunosznicq (rum. miezonoptică). Odprawia się je, jak sama nazwa wskazuje o północy, gdyż cisza nocna sprzyja skupieniu i modlitewnemu obcowaniu z Bogiem. Nabożeństwo to upamiętnia także doniosłe wydarzenia z życia Jezusa (m.in. narodzenie i zmartwychwstanie), które miały mieć miejsce właśnie w nocy. Mnisi wyznają podczas połunosznicy wiarę w powtórne przyjście Chrystusa i Sąd Ostateczny, które według chrześcijańskich wierzeń, będą miały miejsce właśnie o północy. Z drugiej strony, czuwanie o północy rozumiane jest także, jako naśladowanie czuwania aniołów i ich nieustającego wychwalania Boga ${ }^{26}$.

Wczesnym rankiem około godziny piątej rozpoczyna się kolejna modlitwa dobowa, zwana jutrznią (rum. utrenia). Pierwotnie związana była także prawdopodobnie z oczekiwaniem na powtórne przyjście Chrystusa, które - na wzór zmartwychwstania - w wyobrażeniach chrześcijan dokonać ma się w nocy ${ }^{27}$. Symbolika tego nabożeństwa jest bardzo bogata i umieszczona w charakterystycznym czasie - w momencie przełomu nocy i dnia, czyli - w egzegezie chrześcijańskiej - zwycięstwa życia nad śmiercią. Ale Kościół odwołuje się tu przede wszystkim do postaci Chrystusa - prawdziwej Świattości, która oświeca caty świat i ludzkośśc ${ }^{28}$.

Do cyklu dobowego w prawosławiu zaliczane są także tzw. „,czasy (godziny) liturgiczne", które przypadają co trzy godziny, dzieląc dzień na cztery części. Podobnie jak i w katolicyzmie, wytworzyło się tu specjalne, misteryjne znaczenie tych godzin. W czasach współczesnych godziny odczytywane są głównie w monastyrach i tych katedrach, w których zachował się porządek służby monastycznej.

Dzień rozpoczyna tzw. pierwszy czas, zwany także pierwsza godzina (rum. Ceasul I), która ma miejsce na początku pierwszej ćwierci dnia, co odpowiada według na-

23 B. Bobrinskoy, op. cit., s. 43.

24 B. Czywkin, Nabożeństwo wieczorne w cerkwi prawosławnej, [dok. elektr.] www.republika.pl/ bielsktrojka/publikacje/nabozenstwa.doc [odczyt: 2.05.2012].

25 Szerzej na ten temat: E. Branişte, op. cit., s. 66.

${ }^{26}$ Nowe tablice, czyli o cerkwi, liturgii, nabożeństwach $i$ utensyliach cerkiewnych. Objaśnienia Beniamina Arcybiskupa Niżnego Nowogrodu. Wybór, przeł. I. Petrov, Kraków 2007, s. 83.

27 M. Skabałłanowicz, op. cit., s. 35-40.

28 J 1, 9; Mt 3,20; Łuk 1, 78, [w:] Pismo Święte..., op. cit. 
szego czasu około szóstej godzinie rano w czasie od wiosennego do jesiennego przesilenia. W praktyce prawosławia ważne jest, aby modlitwy tego czasu odczytywane były wraz z początkiem dnia. W monastyrach jest odprawiana zwykle po jutrzni, jako jej kontynuacja lub dopełnienie. W modlitwach tych wychwalany jest Bóg, który sprowadził nowy dzień - przyniósł światłość, która zwyciężyła ciemność nocy symbolizującą śmierć. Godzina ta ma przypominać także wiernym o sądzie nad Jezusem Chrystusem, dokonanym przez Piłata i skazaniu Go na śmierć, mający według tradycji miejsce w godzinach porannych ${ }^{29}$.

Kolejną modlitwą dobową jest tzw. trzecia godzina, zwana także trzecim czasem (rum. Ceasul III). Jest ona odmawiana na początku drugiej ćwierci dni, czyli około godziny dziewiatej rano. W praktyce jest także często odmawiana razem z godziną szóstą. Nabożeństwo to jest podziękowaniem Bogu za przebycie tej części dnia, z drugiej - przypomina moment biczowania i obelg, jakich Jezus doznał od prześladowców po sądzie u Piłata. Odczytuje się w nim psalmy 16/17, w którym błaga się Boga o wyzwolenie od wrogów oraz psalm 24 (Dawidowy), będący wyznaniem wiary i prośbą o oczyszczenie z grzechów i nieprawości. Ze względu na to, że nabożeństwo to jest także upamiętnieniem Zesłania Ducha Świętego na Apostołów w dzień Pięćdziesiątnicy ${ }^{30}$, przywołuje się w nim także psalm 50/51, wzywający Trójcę Świętą.

Nabożeństwo szóstej godziny, zwane także szóstym czasem (rum. Ceasul VI), odpowiada porze środka dnia, czyli godzinie dwunastej. Podczas modlitw mnisi dziękują za przebycie połowy dnia i przywołują w pamięci cierpienia Jezusa i moment jego męczeństwa. Odmawiane są psalmy 53/54, 54/55 i 90/91, w których jest mowa o ukrzyżowaniu Jezusa, a także o trzęsieniu ziemi i mroku, które pokryły świat w momencie jego śmierci ${ }^{31}$. Podczas tego nabożeństwa odmawia się także psalm 90, który ma znaczenie symboliczne - przywoływana jest w nim postać Ewy, która utraciła raj przez kuszenie diabła. Wydarzenie to na płaszczyźnie hermeneutycznej jest aluzją do największego niebezpieczeństwa zagrażającego mnichom, czyli acedii, zwanej demonem poludnia. Mnisi ostrzegani są w ten sposób przed zwątpieniem, obojętnością oraz smutkiem, ale i - poprzez ukazanie postaci Ojca, działającego przez swoich posłańców - wspierani nadzieją, że możliwe jest zwycięstwo nad złem działającym w świecie.

Na początku ostatniej ćwierci dnia, czyli ok. godziny trzeciej po południu odmawiane jest nabożeństwo dziewiątej godziny (rum. Ceasul IX), w którym dziękuje się przede wszystkim Bogu za przebycie trzech części dnia. Jest to jednocześnie nabożeństwo zamykające cykl dziennej liturgii godzin. Ustanowione zostało ono także na pamiątkę ukrzyżowania i śmierci Jezusa, która według tradycji ewangelicznej dokonała się właśnie w tym czasie. $Z$ tego powodu przed rozpoczęciem nabożeństwa ude-

\footnotetext{
${ }^{29}$ Mar 14, 65; 15, 15, [w:] Pismo Święte..., op. cit.

${ }^{30}$ Dz. Apost. II, 15, , [w:] Pismo Święte..., op. cit.

${ }^{31}$ Ewangelie przedstawiają czas tego wydarzenia różnie: J XIX, 14; Mt XXVII, 45-46; Mk XV, 33; Łk XXIII, 44, [w:] Pismo Święte..., op. cit.
} 
rza się w biło (toacă) i zapala świece - jedną na ołtarzu, dwie przy ikonach królewskich i jedną w ikonostasie.

\section{Cykl tygodniowy}

Drugim cyklem liturgicznym prawosławnego kalendarza jest tzw. cykl tygodniowy. Obejmuje siedem dni tygodnia, począwszy od niedzieli, która jest pierwszym, a na poziomie symbolicznym także ostatnim jego dniem. Tygodniowy podział czasu w prawosławiu został odziedziczony z tradycji judaizmu ${ }^{32}$. Siedmiodniowy tydzień, zgodnie ze zwyczajem żydowskim, opierał się na opowieści o stworzeniu świata ze Starego Testamentu. Jednak, chrześcijaństwo dokonało tu pewnego wyłomu w stosunku do tradycji żydowskiej. Dla Żydów dzień pierwszy liczył się od momentu stworzenia świata. Dzień siódmy był dniem odpoczynku, czyli szabatem oraz świętem na cześć Jahwe, który zawarł przymierze z ludem żydowskim i wyzwolił go z niewoli egipskiej33. Chrześcijaństwo zachowało nazwy żydowskie, ale dniem pierwszym uczyniło niedzielę - Dzień Pański, czyli dzień Zmartwychwstania Chrystusa i od niego rozpoczyna liczyć dni całego tygodnia. Dlatego też niedziela uznawana jest za najważniejszy dzień tygodnia, dzień, w którym dokonało się zwycięstwo Boga nad złem tego świata, światła i życia nad ciemnością i śmiercią. Jest to dzień radości całej wspólnoty, w którym wierni spotykają się na wspólnej Liturgii i Eucharystii ${ }^{34}$. Niedziela jest symbolem życia przyszłego, wiecznego. Jednocześnie, nazywa się ją często ósmym dniem tygodnia, co symbolizuje jej wyjątkowość - jest punktem wyjścia i zarazem uwiecznienia końca całego tygodnia ${ }^{35}$. Dlatego w tradycji prawosławnej niedziela jest nie tylko końcem tygodnia - dniem zmartwychwstania dokonanego w czasie historycznym, ale i pierwszym dniem tygodnia - oczekiwaniem dnia ósmego, czyli Królestwa Bożego, które nadejdzie w nieznanej przyszłości.

Prawosławie wiąże poszczególne dni tygodnia ze wspomnieniem tajemnic wiary, świętego lub grupy świętych. Postacie wspominane ilustrują najważniejsze szczeble hierarchii świętości, biorące udział w nieustannym wychwalaniu Boga. To także postacie, które kolejno, chronologicznie, pojawiają się na planie zbawienia. W tym znaczeniu tydzień liturgiczny jest ikona, której centrum stanowi zmartwychwstały Chrystus, którego przyjście symbolicznie zapowiadają poszczególne postacie hierarchii, czczone w każdy dzień tygodnia. Często też cykl tygodniowy nazywany jest Pascha tygodniowa ${ }^{36}$, symbolicznie przywołującą poprzez nabożeństwa czasu dobo-

32 B. Bobrinskoy, op. cit., s. 75.

33 Wj 20, 8-11; Wj 31,13, [w:] Pismo Święte..., op. cit.; N. Kos, Święta i obyczaje żydowskie, Warszawa 2002, s. 27-37.

34 S. Făgăraş, Episcopii iau decizii „,trăsnite”. Locul duminicii în calendarul bizantin [dok. elektr.] http://www.oglindanet.ro/index.php?option=com_content\&view=article\&id=632\%3Aepiscopii-iau-deci zii-trsnite-locul-duminicii-in-calendarul-bizantin\&Itemid=54 [odczyt: 23.04.12].

35 Szerzej o tej symbolice: B. Bobrinskoy, op. cit., s. 76.

36 B. Bobrinskoy, op. cit., s. 77. 
wego i wspomnienie świętych czczonych w każdym dniu tygodnia historię zbawienia, mającą swoją kulminację w niedzielnym zmartwychwstaniu.

W tradycji prawosławnej poniedziałek poświęcony jest postaciom pierwszych stopni hierarchii - aniołom i ich orędownictwu za światem i ludzkością. We wtorek w kalendarzu prawosławnym czczony jest św. Jan Chrzciciel, a wraz nim wszyscy prorocy przepowiadający przyjście Chrystusa. Środa jest dniem ciemności - wiąże się go ze zdradą Chrystusa przez Judasza i Matką Bożą, opłakującą Syna pod krzyżem (Stabat Mater). Ten dzień ma charakter pokutny, dlatego w prawosławiu obowiązuje w nim do dziś ścisły post (nie je się mięsa ani nabiału) i wzmożona modlitwa ${ }^{37}$. W czwartek Cerkiew oddaje cześć Apostołom, ojcom Kościoła, Cudotwórcom i Biskupom. Wśród nich szczególnie wyróżnia św. Mikołaja, wzór wstrzemięźliwości, ubóstwa i pokory dla wszystkich hierarchów i wiernych ${ }^{38}$. Piątek przywołuje pamięć i tajemnicę Krzyża Świętego oraz śmierci Jezusa; jest to kolejny dzień ciemności, który musi być przezwyciężony przez odpowiednie zachowanie - modlitwę, post i jałmużnę ${ }^{39}$. Jest dniem przygotowania do wielkiego święta, czyli zmartwychwstania (piątek w j. greckim - Paraskevi - Dzień Przygotowania (rum. Ziua Pregătirii) ${ }^{40}$.

W sobotę - ostatnim dniu tygodnia - wspomina się Matkę Bożą, choć trzeba zaznaczyć, że jest ona wspominana codziennie we wszystkich oficjach, a szczególnie W niedzielę, środę i piątek. Jednocześnie, ze względu na śmierć Jezusa i Jego przebywanie w grobie, sobota jest poświęcona wszystkim świętym zmarłym. W ten dzień Kościół wspomina zatem męczenników, ascetów oraz wszystkich, którzy zasnęli w Panu z nadzieją zmartwychwstania ${ }^{41}$. W tym dniu nasilają się modlitwy za zmarłych. Szczególnie jest to widoczne w tzw. rodzicielskie soboty (potocznie: Dziady), przypadające kilka razy do roku. Najważniejsze z nich odbywają się w soboty Wielkiego Postu, w sobotę przed ruchomym świętem Zesłania Ducha Świętego (Rusalii), w sobotę przed św. Dymitra (26 października). W te soboty Cerkiew szczególnie nawołuje do modlitwy nie tylko za bliskich, ale za wszystkich chrześcijan zmarłych w różnych okolicznościach.

Cykl nabożeństw tygodniowych zawarty jest w księdze zwanej Oktoich, zredagowanej w VIII w. przez św. Jana Damasceńskiego ${ }^{42}$. Jej nazwa pochodzi od ośmiu tonów (melodii, głosów), nawiązujących do symboliki ósmego dnia. Księga zawiera materiał liturgiczny przeznaczony dla nabożeństw w ciągu tygodnia, rozdzielony na osiem tonów powtarzających się co 8 tygodni. Cykl pieśni jednego tygodnia śpiewa się w jednym z ośmiu tonów, a więc wszystkie osiem tonów wykonuje się w ciągu ośmiu tygodni, a cały ten cykl można powtórzyć w roku najwyżej sześć razy.

${ }^{37}$ Mk 9, 2, [w:] Pismo Święte..., op. cit.

${ }^{38}$ ks. A. C. Calivas, op. cit., s. 58.

${ }^{39}$ ks. A. C. Calivas, op. cit., s. 58-59.

${ }^{40}$ M. Rautman, op. cit., s. 5.

41 ks. A. C. Calivas, op. cit., s. 58.

42 Oktoih, sirêč osmoglasnik, malyj, obderžaj Voskresnu službu osmi glasov, red. J. Charkiewicz, Warszawa 2007; Oktoich, [dok. elektr.] http://www.liturgia.cerkiew.pl/docs.php?id=24 [odczyt: 22.06.12]. 
Nabożeństwa według Oktoicha odprawiane są poczynając od drugiej niedzieli po święcie Zesłania Ducha Świętego na Apostołów i kończą się w Niedzielę Faryzeusza i Celnika, przypadającą w pierwszą niedzielę Przedpościa ${ }^{43}$.

\section{Cykl roczny}

Prawosławny rok kościelny rozpoczyna się według praktyki bizantyjskiej 1 września. Dzień ten w tradycji prawosławnej nazywany jest także początkiem Indyktionu, czyli nowego roku liturgicznego. Cerkiew świętuje w ten dzień wydarzenie przybycia Chrystusa do świątyni, ukazania się zebranym i Jego nauczania. Tego dnia w cerkwi na wielkich nieszporach, po odczytaniu fragmentu proroctwa Izajasza, mówiącego o nadejściu roku laski Pana znanego z liturgii synagogalnej, przytaczane są jeszcze fragmenty Księgi Kapłańskiej i Księgi Mądrości Salomona, mówiące o grzechu zamykającym drogę do mądrości i odmiennych losach tych, którzy dochowują przymierza z Jahwe i tych, którzy od niego odchodzą poprzez grzech ${ }^{44}$. Teksty te są uzupełnione na jutrzni poprzez przywołanie ewangelicznej opowieści o przyjściu Jezusa wraz $\mathrm{z}$ apostołami na równinę Tyru, Jego nauczaniu, uzdrawianiu z chorób, udzielaniu błogosławieństw oraz o odczytaniu przez niego w synagodze w Nazarecie fragmentu proroctwa Izajasza o namaszczeniu Go przez Ducha Świętego na glosiciela dobrej nowiny $i$ wypetnieniu słów Jahwe ${ }^{45}$. W wydarzeniu tym widzi zapowiedź wypełnienia się Bożego planu zbawienia dla całej ludzkości ${ }^{46}$. Teksty liturgiczne na ten dzień mówią także o Bogu Stwórcy i „Władcy lat i okresów” oraz wyrażają modlitwę i prośbę o błogosławieństwo dla całej ludzkości ${ }^{47}$.

Cykl szczególnie obchodzonych świąt podzielony jest na święta ruchome i nieruchome (pochodne od Wielkanocy). Kościół prawosławny ustala je nie według historycznego, ale według tzw. porządku duchowego, ukazującego Boży plan zbawienia ludzkości. Rytm ten biegnie w cyklu rocznym po kole, zataczając krąg, w którym rokrocznie powtarzają się te same święta. Powtarzające się w rocznym cyklu wydarzenia dotyczą najważniejszych i decydujących z punktu widzenia zbawienia ludzkości momentów z życia Jezusa. Kościół prawosławny ma świadomość, że wydarzenia te miały miejsce tylko raz w przeszłości, ale pamięć o nich i ich celebrację w historii

\footnotetext{
${ }^{43}$ ks. T. Kałużny, op. cit., s. 170.

${ }^{44} \mathrm{Kpł}$ 26, 3-21; S1 4, 7-15; Miesiaca września 1 dnia poczqtek indykcji, czyli Nowego Roku, http:// liturgia.cerkiew.pl/pages/File/docs/festum-02-indykcja.pdf [odczyt: 2.05.12].

${ }^{45}$ Iz. 61, 1-2; Łk perykopa 24 (6,17-27); Łk perykopa 13 (4, 16-22), w: Miesiaca września 1 dnia początek indykcji, czyli Nowego Roku, http://liturgia.cerkiew.p1/pages/File/docs/festum-02-indykcja.pdf [odczyt: 2.05.12].

${ }^{46}$ Ks. M. Łanoszka, Abym ubogim glosit dobrq nowinę, http://www.studiumbiblijne.diecezja.tarnow.pl/semestr_III/wyklad_21.pdf [odczyt: 27.08.12].

${ }^{47}$ ks. B. Repeła, Cykl roczny nabożeństw, [dok. elektr.] http://www.lagoszowwielki.radwanice.pl/ clubin/czytelnia/Cykl_roczny_nabozenstw.pdf [odczyt: 2.05.12].
} 
uznaje aż do kresu czasu za podstawowy obowiązek wspólnoty, a także za wprowadzenie w przyszły czas ${ }^{48}$.

Najważniejszym świętem, jak w całym chrześcijaństwie, jest Pascha, czyli Zmartwychwstanie Jezusa Chrystusa, święto ruchome, przypadające w niedzielę po pierwszej wiosennej pełni księżyca po wiosennym zrównaniu dnia z nocą. Pascha jest najstarszym, a zarazem najbardziej radosnym i uroczystym świętem Kościoła chrześcijańskiego, wywodzącym się z żydowskiego święta Pesah ${ }^{49}$.

Po Wielkanocy, typikon Kościoła wschodniego wyróżnia trzy kategorie świąt wielkie, średnie i małe ${ }^{50}$. Różnią się od siebie zarówno rodzajem nabożeństw odprawianych w dane święto, jak i oznaczeniem w kalendarzu prawosławnym.

Kategoria tzw. 12 najważniejszych świąt prawosławnych poświęcona jest Chrystusowi (tzw. święta Pańskie) i Matce Bożej (tzw. święta Matki Bożej). Trzy spośród nich są ruchome, a dziewięć nieruchomych. Są to kolejno święta:

- 8/21 września - Narodzenia Bogarodzicy (rum. Naşterea Maicii Domnului) święto nieruchome

- 14/27 września - Podwyższenia Krzyża Świętego (rum. Înălțarea Sfintei Cruci) - święto nieruchome

- 21 listopada/4 grudnia - Wprowadzenia Bogarodzicy do Świątyni (rum. Intrarea Maicii Domnului în Biserică) - święto nieruchome

- 25 grudnia/7 stycznia - Bożego Narodzenia (rum. Naşterea Domnului) święto nieruchome

- 6/19 stycznia - Chrztu Pańskiego (rum. Botezul Domnului), zwane także Epifanią lub Objawieniem Pańskim (rum. Aratarea Domnului) - święto nieruchome

- 2/15 lutego - Spotkania Pańskiego, Przedstawienia Chrystusa w świątyni (rum. Intâmpinarea Domnului) - święto nieruchome

- 25 marca/7 kwietnia - Zwiastowania Bogarodzicy (rum. Bunavestirea Maicii Domnului) - święto nieruchome

- Kwietna Niedziela (rum. Duminica a Floriilor) - święto ruchome, zależne od daty Wielkanocy, przypadające zawsze w szóstą Niedzielę Wielkiego Postu, czyli w ostatnią niedzielę przez świętem Paschy

- Wniebowstąpienia Pańskiego (rum. Inălțarea Domnului) - święto ruchome, zależne od daty Wielkanocy, przypadające zawsze w czwartek czterdzieści dni po Wielkanocy.

48 ks. A. C. Calivas, op. cit., s. 51-52.

${ }^{49}$ ks. A. C. Calivas, op. cit., s. 62-63; Bp Abel (Popławski), Święta Pascha - Zmartwychwstanie Chrystusa, [w:] Prawosławie. Światło wiary i zdrój doświadczenia, red. K. Leśniewski, K. Leśniewska, Lublin 1999, s. 101; ks. J. Naumowicz, Geneza chrześcijańskiej rachuby lat. Historyczno-teologiczne podstawy systemu Dionizego Mniejszego, Kraków 2000.

50 М. Скабалланович, Толковый Типикон, [dok. elektr.] http://www.orthodox.ee/docs/t_typikon. pdf [odczyt: 1.06.12]. 
- Zesłania Ducha Świętego (rum. Pogorârea Sfintului Duh) - święto ruchome, zależne od daty Wielkanocy, przypadające zawsze w ósmą niedzielę (tj. pięćdziesiąt dni) po Wielkanocy, zwane także Pięćdziesiatnica (rum. Cincizecimea).

- 6/19 sierpnia - Przemienienia Pańskiego (rum. Schimbarea la Față a Domnului) - święto nieruchome

- 15/28 sierpnia - Zaśnięcia Bogarodzicy (rum. Adormirea Maicii Domnului) - święto nieruchome

Pozostałe dni kalendarza prawosławnego poświęcone są postaciom z tradycji Kościoła chrześcijańskiego, zarówno historycznym, jak i legendarnym, kanonizowanym i podzielonym na różne stopnie hierarchii - prorokom, apostołom, anachoretom, ojcom kościoła, męczennikom i innym świętym. Dzielą się one na tzw. święta średnie, oznaczane w kalendarzu kolorem zielonym. Są to m.in. święto Obrzezania Pańskiego (1/14 stycznia), Trzech Wielkich Hierarchów i Nauczycieli Kościoła Bazylego Wielkiego, Grzegorza Teologa i Jana Teologa (30 stycznia/12 lutego), Wielkiego Męczennika Jerzego (23 kwietnia/6 maja), Narodzenie proroka Jana Chrzciciela (24 czerwca/7 lipca), Świętego Męczennika Dymitra (26 października/8 listopada). Trzecią kategorię świąt stanowią tzw. święta małe, które oznacza się w kalendarzu kolorem czarnym. Są to np. Początek Nowego Roku Kościelnego (1/14 września), Niedziela Przebaczenia Win (święto ruchome, pochodne od Wielkanocy).

Poza świętami wspólnie obchodzonymi przez cały świat prawosławny, istnieje w Rumunii, podobnie jak i w innych kościołach prawosławnych, kategoria tzw. świętych lokalnych, obchodzonych przez daną Cerkiew, związanych szczególnie z tradycją i historią narodu. Kościół wschodni poświęcił dodatkowo jeden dzień w kalendarzu, w którym każdy kościół narodowy obchodzi święto uczczenia tzw. świętych lokalnych ${ }^{51}$. W Rumunii obchodzi się go w drugą niedzielę po Pięćdziesiątnicy, która zwana jest Niedzielą Świętych Rumunów (rum. Duminica a Sfinților Români). Kalendarz prawosławny jest otwarty, a co za tym i idzie, uzupełniany. W Rumunii po upadku reżimu Nicolae Ceauşescu, symboliczne uroczystości odbyły się w 1992 roku, kiedy to Święty Synod Rumuńskiego Kościoła Prawosławnego, wyświęcił i wpisał do kalendarza kolejnych czternastu świętych, w większości lokalnych, m.in. pustelnika Daniela Hezychastę $^{52}$, mołdawskiego hospodara Stefana Wielkiego ${ }^{53}$, św. Teodorę z Sihla ${ }^{54}$,

51 ks. A. C. Calivas, Oddawanie czci Bogu, [w:] Prawosławie. Światło wiary i zdrój doświadczenia, red. K. Leśniewski, J. Leśniewska, Lublin 1999, s. 51-70.

52 C. Turcu, Danil Sihastru. Figură istorică, legendară şi bisericească, Iaşi 1947, s. 6; Sfintul Cuvios Daniil Sihastru, [w:] Sfinți români din Bucovina, Arhiepiscopia Sucevei şi Rădăuţilor, Suceava 1992 , s. 119-160; Canonizarea unor sfinți români (20-21 iunie 1992)..., op. cit., s. 50-48-51.

53 Demciuc V. M., Binecredinciosul domn şi apărătorul dreptei credințe - Ştefan cel Mare şi Sfânt, Suceava 1999; Eşanu A., Eşanu V., Epoca lui Ştefan cel Mare. Oameni-destine - fapte, Ed. Institutului Cultural Român, Bucureşti 2004.

${ }^{54}$ E. Kocój, Karpacka Święta z Rumunii, [w:] W kręgu relacji polsko-rumuńskich. Materiaty z sympozjum, red. St. Jakimowska, E. Wieruszewska, Suczawa 2010, s. 409-418. 
czy św. Jana Jakuba z Neamț ${ }^{55}$. W 2007 r. do świętych tego kalendarza dołączył metropolita Barlaam (XVII w. $)^{56}$. W Rumunii, podobnie jak w innych krajach prawosławnych, istnieją także tzw. święta chramowe, integrujące zwłaszcza społeczności zamieszkałe w jednej parafii, obchodzone ku czci patrona danej świątyni.

W rumuńskim prawosławnym roku kościelnym występują cztery główne okresy postne i tzw. dni postne ${ }^{57}$. Najważniejszymi okresami postnymi są:

1. Wielki Post (rum. Postul Mare) - post o charakterze ruchomym, w zależności od daty Wielkanocy, trwający czterdzieści dni (7 tygodni).

2. Post świętych Apostołów Piotra i Pawła (rum. Postul Sfintilor Apostoli Petru şi Pavel) - post, którego długość pochodna jest od święta Wielkanocy i może trwać od jednego do sześciu tygodni przed świętem Piotra i Pawła (29 czerwca/12 lipca). Rozpoczyna się w poniedziałek, 8 dni po święcie Pięćdziesiątnicy i kończy 28 czerwca/11 lipca, w wigilię św. Piotra i Pawła.

3. Post przed świętem Zaśnięcia Matki Bożej (rum. Postul Adormirii Maicii Domnului ) - trwający 14 dni, od 1/14 do 14/27 sierpnia

4. Post przed Bożym Narodzeniem (rum. Postul Naşterii Domnului) - trwający 40 dni. W Rumunii post ten rozpoczyna się 14/27 listopada i trwa do 24 grudnia/6 stycznia.

Pojedyncze dni postne obchodzone są przed świętem Podniesienia Krzyża Pańskiego (14 września), Ścięcia Głowy Jana Chrzciciela (29 sierpnia), Objawienia Pańskiego (5 stycznia). Ponadto, kanoniczny post obowiązuje także wiernych na poziomie tygodniowym, dlatego środa i piątek każdego tygodnia uznawane są za dni postne.

Kalendarz liturgiczny używany w Kościele prawosławnym w Rumunii sięga swoimi korzeniami odległych czasów starożytności. Jego struktura ukształtowała się na terenie Bizancjum, a dzięki tradycji przetrwała aż do wieku XX. Kultura religijna, w tym zwyczaje i wierzenia wywodzące się jeszcze z czasów bizantyjskich, uległy jednak w czasie komunizmu na terenie Rumunii ogromnemu zubożeniu. Przemyślany program niszczenia kultury duchowej podczas reżimu Nicolai Ceauşescu doprowadził do częściowego zaniku tradycyjnych rytuałów prawosławia lub przemiany ich w spektakl folklorystyczny. Mimo przemian kulturowych, dokonujących się wraz z upływem czasu, po upadku komunizmu w kulturze religijnej Rumunii następuje odnowa prawosławia, w ramach której powraca się do tekstów liturgicznych i literackich powstałych jeszcze na terenie Bizancjum, a wraz z nimi częściowo ożywają dawne wierzenia, zwyczaje i rytuały ukształtowane jeszcze w tym okresie chrześcijaństwa.

55 L. Florea, Cuviosul Ioan Iacob de la Neamț (Hozevitul), [w:] Sfinți români şi apărători ai legii strămoşeşti, Bucureşti 1987, s. 543-549; J. Charkiewicz, E. Kocój, Rumuńscy święci, Hajnówka 2012 , s. 67-71 (w druku).

56 Sfântul Varlaam al Moldovei, [dok. elektr.] http://www.crestinortodox.ro/sfinti/sfantul-varlaammoldovei-73059.html [odczyt: 23.06.12].

57 O symbolice postu w tradycji prawosławnej zob.: N. D. Necula, Învățătura despre Post in Biserica Ortodoxa [dok. elektr.] http://www.crestinortodox.ro/paste/postul-pastelui/invatatura-despre-post-biserica -ortodoxa-71105.html [odczyt: 23.05.12]. 


\section{Wybrana bibliografia:}

Abel (Popławski), Bp, Święta Pascha - Zmartwychwstanie Chrystusa, [w:] Prawosławie. Światto wiary i zdrój doświadczenia, red. K. Leśniewski, K. Leśniewska, Lublin 1999

Baboş A., Tracing a Sacred Building Tradition, Wooden Churches, Carpenters and Founders in Maramureş until the turn of the 18th century, Norrköping: Lunds Universitet, 2004.

Balş G., Bisericile lui Ştefan cel Mare, Bucureşti 1926.

Balş G., Bisericile şi mănăstirile moldoveneşti din veacul al XVI-lea, București 1928.

Bebis G. S., Święta Tradycja, [w:] Prawostawie. Światto ze Wschodu, red. K. Leśniewski, Lublin 2009, s. 17-24.

Bobrinskoy B., Życie liturgiczne, Warszawa 2004.

Bondaruk K., ks., Nauka o nabożeństwach prawosławnych, część II, Białystok 1987, s. 72.

Bondaruk K., ks., Nabożeństwa cyklu dobowego - cz. II, Wieczernia, powieczerze, jutrznia [http://www. old.cerkiew.pl/prawoslawie/text.php?id=247].

Branişte E., Liturgica speciala, Bucureşti 2005.

Calivas A. C., ks., Oddawanie czci Bogu, [w:] Prawosławie. Światto wiary i zdrój doświadczenia, red. K. Leśniewski, J. Leśniewska, Lublin 1999, s. 64-65.

Ceaslov tipărit cu aprobarea Sfântului Sinod şi cu binecuvântarea prea Fericitului Părinte Teoctist Patriarhul Bisericii Ortodoxe Române, Bucureşti 2001.

Chipuri de viață monahală, Mănăstirea Sihăstria Putnei 2006.

Cieślik I., Starcy Pustyni Optyńskiej, Kraków 2005.

Crăciunaş Suceveanul I., Bisericile cu pictură exterioară din Moldova (I), [w:] „Mitropolia Moldovei şi Suceavei", 1969, $\mathrm{nr}$ 7-9.

Crăciunaş Suceveanul I., Bisericile cu pictură exterioară păstrată parțial, [w:] Bisericile cu pictură exterioară din Moldova (II), [w:] „Mitropolia Moldovei şi Suceavei”, 1970, nr 3-6.

Czywkin B., Nabożeństwo wieczorne w cerkwi prawosławnej [dok. elektr.] www.republika.pl/bielsktroj$\mathrm{ka}$ /publikacje/nabozenstwa.doc

Demciuc V.M., Binecredinciosul domn şi apărătorul dreptei credințe - Ştefan cel Mare şi Sfânt, Suceava 1999.

Dokumenty Soborów Powszechnych. Tekst grecki, taciński, polski, T. I (325-787), opr. ks. A. Baron, ks. H. Pietras SJ, Kraków 2003.

Dziewiqta godzina [dok. elektr.] http://www.liturgia.cerkiew.pl/pages/File/docs/hora-07-nona.pdf [odczyt: 1.06 .12$]$.

Florea L., Cuviosul Ioan Iacob de la Neamț (Hozevitul), [w:] Sfinți români şi apărători ai legii strămoşeşti, Bucureşti 1987, s. 543-549.

Hotărâre nr. 90 din 10/02/2010, privind organizarea si functionarea Ministerului Culturii si Patrimoniului National, [dok. elekt.] http://mail.cultura.ro/cultura/uploads/files/HG-90-2010-MCPN.pdf [odczyt: 10.04.12].

Jakub (Kostiuczuk), bp, Monastycyzm wschodni, [w:] Życie monastyczne w Rzeczypospolitej, red. A. Mironowicz, U. Pawluczuk, P. Chomik, s. 11-22

Janocha M., ks., Ukraińskie i biatoruskie ikony świateczne w dawnej Rzeczypospolitej, Warszawa 2001.

Kałużny T., SCJ, Kalendarz liturgiczny w rycie bizantyjskim, [w:] : Czas i kalendarz, red. Z. Kijas, Kraków 2001, s. 173-180.

Kocój E., Karpacka Święta z Rumunii, [w:] W kręgu relacji polsko-rumuńskich. Materiały z sympozjum, red. St. Jakimowska, E. Wieruszewska, Suczawa 2010, s. 409-418.

Kocój E., Światynie, postacie, ikony. Malowane cerkwie i monastyry Bukowiny Poludniowej w wyobrażeniach rumuńskich, Kraków 2006.

Kowalski P., Kultura magiczna: omen, przesqd, znaczenie, Warszawa 2007.

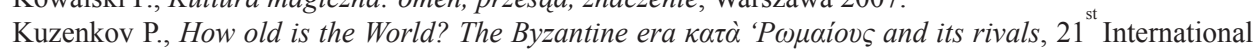
Congress of Byzantine Studies, London 2006, Communication (I.2 Theories of Empire) [dok. elektr.] http://www.wra1th.plus.com/byzcong/comms/Kuzenkov_paper.pdf [odczyt 23.06.12]. 
Maximos (E. Aghiorgoussis), Bp, Monastycyzm, [w:] Prawosławie. Światto wiary i zdrój doświadczenia, Lublin 1999, s. 133-142.

Miesiqca września 1 dnia poczatek indykcji, czyli Nowego Roku, http://liturgia.cerkiew.pl/pages/File/ docs/festum-02-indykcja.pdf [odczyt: 2.05.12].

Miu L., Badea E., Researcg form conservation and restoration of movable cultural heritage. Advanced techniques leather and parchement.

The Romanian case [dok. elektr.] http://exchange.kumid.eu/pdf/miu_and_badea.pdf [odczyt: 1.02.12].

Naumowicz J., ks., Geneza chrześcijańskiej rachuby lat. Historyczno-teologiczne podstawy systemu Dionizego Mniejszego, Kraków 2000.

Necula N. D., Invățătura despre Post in Biserica Ortodoxa [dok. elektr.] http://www.crestinortodox.ro/paste/postul-pastelui/invatatura-despre-post-biserica-ortodoxa-71105.html [odczyt: 13.03.12].

Nicolescu C., Arta în epoca lui Ştefan cel Mare. Antecendentale şi etapele de dezvoltare ale artei moldoveneşti din-epoca lui Ştefan cel Mare, [w:] Cultura moldovenească în timpul lui Ştefan cel Mare, red. M. Berza, Bucureşti.

Nowe tablice, czyli o cerkwi, liturgii, nabożeństwach i utensyliach cerkiewnych. Objaśnienia Beniamina Arcybiskupa Niżnego Nowogrodu. Wybór, przeł. I. Petrov, Kraków 2007, s. 83.

Oktoih, sirêč osmoglasnik, malyj, obderžaj Voskresnu službu osmi glasov, red. J. Charkiewicz, Warszawa 2007.

Oktoich, [dok. elektr.] http://www.liturgia.cerkiew.pl/docs.php?id=24 [odczyt: 22.06.12].

Patsavos L., Kalendarz liturgiczny, [w:] Prawostawie. Światto wiary i zdrój doświadczenia, red. K. Leśniewski, J. Leśniewska, Lublin 1999, s. 72-73.

Patterson J., Wooden Churches of the Carpathians. A Comparative Study, East European Monographs, Boulder Distributed by Columbia University Press, New-York, 2001.

Pismo Święte Starego i Nowego Testamentu. Biblia Tysiqclecia, Poznań 2007

Porzqdek nieszporów, tł. ks. H. Paprocki, pełny tekst: http://www.liturgia.cerkiew.pl/pages/File/docs/hora-08-nieszpory.pdf [dostęp 27.12.2011].

Przybył E., Prawosławie, Kraków 2000.

Rautman M., Daily Life in the Byzantine Empire, Greenwood Publishing Group, 2006 [dok. elektr.] http:// books.google.ca/books?id=hs3iEyVRHKsC \& printsec $=$ frontcover $\& d q=$ Daily + Life + in + the + Byzan tine+Empire $\# \mathrm{v}=$ onepage $\& \mathrm{q}=$ Daily $\% 20 \mathrm{Life} \% 20 \mathrm{in} \% 20$ the $\% 20$ Byzantine $\% 20$ Empire $\& \mathrm{f}=$ false

Repeła B. ks., Cykl roczny nabożeństw [dok. elektr.] http://www.lagoszowwielki.radwanice.pl/clubin/czy telnia/Cykl_roczny_nabozenstw.pdf [27.05.12].

Rohrscheidt-Schwaben A. F. v., Historia liturgii chrześcijańskiej, [dok. elektr.] http://www.kus.mikronacje.info/node/171 [odczyt: 3.05.12].

Romania [dok. elektr.] http://whc.unesco.org/en/statesparties/ro [odczyt: 2.04.12];

Sfântul Varlaam al Moldovei, [dok. elektr.] http://www.crestinortodox.ro/sfinti/sfantul-varlaam-moldovei73059.html [odczyt: 23.06.12].

Smykowska E., Liturgia prawosławna, Warszawa 2008.

Sołowjew A., Ojcowie cerkwi o starcostwie i monastycyzmie, tł. S. Maria (Jurczuk), Hajnówka 1997.

Skabałłanowicz M., Tołkowyj Tipikon. Objasnitielnoje izłożenija Tipikona s istoriczeskim wwiedienijem, Moskwa 2004

Скабалланович М., Толковый Типикон, [dok. elektr.] http://www.orthodox.ee/docs/t_typikon.pdf [odczyt: 1.06.12]

Tipicul cel Mare al sfintului Sava cel Sfintit, [dok. elektr.] http://www.crestinortodox.ro/carti-ortodoxe/ tipicul-mare-sfantului-sava-sfintit/randuiala-vecerniei-celei-mici-82729.html

Wąsowicz H., Kalendarz chrześcijański, w: Czas i kalendarz, red. Z. Kijas, Kraków 2001, s. 77-115.

Wąsowicz H., Kalendarz juliański i gregoriański, [w]: Czas i kalendarz, red. Z. Kijas, Kraków 2001, s. $117-158$.

Woźniak Z., ks., Głos Karmelu, nr 6 (42), listopad-grudzień 2011.

Żywot i Pisma świętego Bazylego Wielkiego, opr. hieromnich Gabriel Hagioryta, J. Misiejuk, Hajnówka (b.r.w.) 


\title{
THE LITURGICAL CALENDAR OF THE ORTHODOX CHURCH IN ROMANIA - A LOCAL TRANSFORMATION OF THE BYZANTINE TRADITION
}

\begin{abstract}
Summary
The liturgical calendar used in the Orthodox Church in Romania dates back to the remote times of antiquity. The structure of the calendar was decisively formed in the period of Byzantium and its use was upheld by the tradition until the $20^{\text {th }}$ century.

The article describes the organization of the Orthodox calendar in Romania. It is divided into three cycles which designate the most significant holidays as well as customs and habits observed by the believers. The basic course is the daily cycle, which allows monks to live according to a specific rhythm determined by prayer, work and rest. It consists of seven prayers that fall at the same times of day and night. The weekly cycle includes seven days of the week starting with Sunday that is the first and at the same time the last day of the week on a symbolic level. Orthodox religion associates particular days of the week with remembering the mystery of faith, a saint or a group of saints. The liturgical week is an icon in the middle of which the Orthodox place Jesus Christ, thus it is often called a Weekly Passover. It symbolically invokes the history of salvation. The annual cycle is divided into the moveable and immoveable feasts (derived from Easter). The Orthodox Church appoints them according to the spiritual, not historical order. The spiritual order displays God's plan to save humanity. This routine makes a full circle every year, with the same holidays placed along the course.

A deliberate plan to destroy spiritual culture by communist authorities led to partial disappearance of Orthodox traditional customs or transformed them into a folk spectacle. The Communism has fallen and we can witness the resurrection of the Orthodox culture. There is a great return to the liturgical texts as well as to belles lettres created in the Byzantine time. Beside them, the old beliefs, habits and rituals molded in the Byzantine Christianity are slowly brought back to life.
\end{abstract}

